\title{
ECONOMIC DEVELOPMENTS IN THE MIDDLE EAST
}

\begin{abstract}
$\mathrm{N}$ a report dealing with developments for the year 1957-58, published by the United Nations as a supplement to the world economic survey of 1958 , there is included a useful survey of agricultural production and development, industry, petroleum production, and foreign trade in the several main countries included in this politically highly sensitive world region (Iran, Iraq, Israel, Jordan, Lebanon, Saudi Arabia, Sudan and Turkey). About one half of the text deals with factual summaries, and about one half gives statistical tables (Economic Developments in the Middle East, 1957-1958. (Supplement to World Economic Survey, 1958.) Pp. viii +104 (New York: United Nations; London: H.M. Stationery Office, 1959.) 1.25 dollars; 9s.; 5 Swiss francs).

The information given regarding the key product, oil, has special interest. The rapid recovery and expansion of this industry during 1957 (after the decline in production as a result of the Suez crisis) is remarkable. In 1957 there was an increase over 1956 of only 3.7 per cent, but this advanced by a further increase of 20.7 per cent in 1958. The total production of the Middle East as a share in world production rose to $23 \cdot 6$ per cent in 1958 as compared with 20 per cent in 1957. The main contributors to the large rise in oil production were Iran and Kuwait, but though producing relatively small quantities, other countries have been expanding their output at a high rate, and a new entrant was Syria where, in the north-east of the country, a field was discovered in 1958 estimated to have an output capacity of about 2 million tons. Agricultural production in the same year shows continued expansion at the rate
\end{abstract}

of about 3 per cent per annum, both in food production and in the output of industrial cash crops on which the several countries depend as a major source of foreign exchange. It is significant that the rate of growth in both exceeded the growth of population. A continued shift in the pattern of production towards industrial cash crops and greater use of fertilizers and agricultural machinery helped to maintain the rate of agricultural output, but the uncertainty of climatic conditions caused wide fluctuations.

Apart from the physical difficulties affecting production within the region, two comprehensive programmes of agrarian reform were started in the Syrian region and in Iraq late in 1958, and the social change and redistribution of income that these are likely to produce will very probably have a strong impact on the shape of future economic development. From these economic changes within, there emerges a picture of foreign trade and payments showing much variation, and with interesting evidence of change in operation leading to shifts in the geographical direction of trade, partieularly of the cotton exporting countries; thus the United Arab Republic and Sudan moved away from Western Europe and the United States toward the U.S.S.R., Eastern Europe and the Far East. Iran, Jordan, Turkey and Israel, on the other hand, maintained their high share of trade with the United States and Western Europe, although an increasing proportion of the exports of Israel and Turkey went to eastern European countries in 1957 and 1958. Oil exports show a sig. nificant increase in their share to Asia and the Far East, though the dominant traditional markets in Western Europe are maintained. Alice GarnetT

\section{THE NATURE OF POLISHED METAL SURFACES}

$\mathrm{H}^{\circ}$ OOKE, Newton and Herschel all held that the asperities in a roughly ground surface are cut away during polishing, leaving a series of fine grooves; the finer the polish the finer these grooves or 'scratches'. Rayleigh agreed that the asperities are worn down but thought that the material is removed in an almost molecular fashion. In 1921 Beilby advanced the radical view that, instead of the asperities being worn away, the depressions in the surface are filled in by material which is smeared across the surface, covering it with a layer which he thought was glass-like or amorphous in character. This has come to be known as the 'Beilby layer'. The idea of the layer being truly amorphous has been modified slightly in more recent times, but the basic concept of a layer which is physically distinct from the substrate and which has lost its obvious erystalline properties is still retained.

Beilby did not propose any specific smearing mechanism, although he inferred that surface tension forces were responsible. A most plausible mechanism was afterwards advanced by Bowden and Hughes which was based on observations that very high local temperatures can be attained when two solids rub past one another. They suggested that asperities in the surface are melted when abrasive particles rub across them, the liquid so formed depositing in and filling adjoining depressions. It was further proposed that, due to very rapid chilling, this molten material solidifies in an amorphous-like condition.

A paper by L. E. Samuels reviews work carried out at the New South Wales Branch of Defence Standards Laboratories which strongly supports the earlier view that polishing is essentially a fine cutting process, and is believed to establish with reasonable certainty that the Beilby layer does not exist.

The new theory is that metallographic polishing occurs primarily by cutting, the individual abrasive particles acting in a similar manner to a planing tool. Material is removed and scratches are produced; the better the polish the finer the scratches. The surface is crystalline but deformed, the magnitude of the deformation decreasing with increasing fineness of polish to a surprisingly low level in the case of the finest polishes. Moreover, the deformation decreases rapidly with depth so that comparatively perfect material is exposed by a very light etch (Austral. J. Sci., 21, 6; 1959). 